\title{
THE CONCEPT OF FILIAL PIETY IN EAST ASIAN CONFUCIAN CULTURE FROM THE PERSPECTIVES OF GADAMER AND HABERMAS ${ }^{1}$
}

\author{
Donghyun Kim \\ Institute of Public Policy \& Administration \\ Chung-Ang University \\ dkim0007@gmail.com
}

\begin{abstract}
This paper examines the role of filial piety in East Asian Confucian societies as a means of drawing out political implications by showing two different standpoints elaborated by Gadamer and Habermas. The two thinkers seem to display different outlooks on the notion of filial piety in the East Asian Confucian culture: Whereas Gadamer appears to approve the practice of filial piety as keeping tradition in the specific societies, i.e., Confucian East Asian culture, Habermas rejects it by refusing the concept of tradition. The debate primarily originates from two different-though both "Western"-philosophical traditions. Gadamer endorses tradition since all human beings are conditioned by the effects of cultural heritage, and events can never be disinterested. All previous contexts of human culture enter into the greater tradition that is transmitted to us through the generations as an inexhaustible stock of moral instruction. On the other hand, in his critique of Gadamer's appropriation of tradition, Habermas argues that human beings can overcome the dogmatic force of tradition. In Habermas's account, it is of significant importance to use reason-or critical reflection-in order to overcome such dogmatic force. In short, this paper appropriates Habermas's charge that Gadamer hypostatizes tradition. In other words, Gadamer's philosophical hermeneutics embeds understanding in tradition because all understanding is necessarily prejudiced. Habermas rejects Gadamer's idea of tradition on the ground that it is absolutizing.
\end{abstract}

\section{Keywords}

Confucianism; Confucian East Asian culture; critical reflection; filial piety; Gadamer; Habermas; tradition 


\section{About the Author}

Donghyun Kim is a senior fellow at the Institute of Public Policy \& Administration at ChungAng University. His main areas of study are contemporary political thought, critical theory, hermeneutics, and existentialism, with specific focus on the relationship between politics and the concept of prejudice (Vorurteil) and tension between "philosophy of Being" and "politics of Becoming." 


\section{INTRODUCTION}

Confucian East Asian societies are fundamentally characterized by explicit social hierarchy. In other words, the hierarchy that structures relationships between parents and children, males and females, and ruler and ruled, is what conditions conventional morality in Confucian tradition. The hierarchical foundation of the family and society, expressed in terms of three bonds (Sangang, 三綱; fatherson, husband-wife, and ruler-ruled), ${ }^{2}$ is the aspect of Confucian tradition that is most criticized. Social hierarchy is also reinforced by the continuity of relations with one's parents long into one's adulthood. Even today, Asian adults have close, dependent ties to their parents. This is intended as an expression of compassion and respect for those who gave life to, nurtured, and taught one to behave in a civilized fashion, but often, this dependency infantilizes an otherwise grown person by subordinating one to parental demands. It is a discourse wherein Confucian cultural issues lie in an understanding of how those values are manifested in the lives of those who inherit the tradition and authority. The unconditional instilling of hierarchical relationships, of tradition and authority that serve as the standards of East Asian Confucian culture, provides the basis of judgment for each member of the society. The emphasis on filial piety as a means of upholding the Confucian values of tradition and authority should be reconsidered to raise doubts concerning these problems.

This paper examines the possibilities for the normative grounding of the role of reason and tradition by focusing on Gadamer and Habermas-with particular reference to an analysis of filial piety as practiced in East Asian culture. It places great weight on the concept of filial piety, particularly because it is a significant cultural practice to explore the normative underpinning of tradition. Gadamer's standpoint locates the conditions of authority in tradition, while Habermas offers a theory of communicative action that transcends the limited horizons of tradition. The concept of filial piety is a phenomenon specific to Confucian East Asian culture. However, it can be used as a tool in exploring whose argument, Gadamer's or Habermas's, has more relevance. ${ }^{3}$ The essential problem with filial piety is that it appears incompatible with the values of freedom and equality. This is due to the most important principle of filial piety: that the children must yield unconditionally to their parents' authority. Habermas's critical perspective can break open the power relations at the heart of filial piety, yet this should not be interpreted as a rejection of respect for parents. Rather, it is a demand for the reorientation of that relationship - and by extension, the relationship to political authority-away from tradition to reason.

The debate between Habermas and Gadamer concerns the status and authority of tradition and the legitimatization of political authority. This debate mirrors the 
one found in moral philosophy concerning the status of values. We are accustomed to saying that values express freedom and creative spontaneity-that is, its capacity to both assess and develop projects. On the other hand, there appears to be a hierarchy of values that we receive and that we ought to acknowledge as something not merely created or established by choice. Values appear to be able to orient our actions only because, in the final analysis, they do not depend on us for their validity. In examining the different positions of Habermas and Gadamer, Habermas sees that uncritical authority and tradition can be improved by means of critical reflection, while Gadamer contends that tradition and authority should be maintained. This paper investigates the concept of filial piety, which is one of the most important characteristics of Confucian East Asian culture, through the lens of Habermas and Gadamer, and their debate about tradition. Using filial piety as a focus, it will try to explain the difference in the positions of Habermas and Gadamer in their abstract philosophical debate in a more concrete manner.

\section{CONFUCIANISM AND THE CONCEPT OF FILIAL PIETY}

Confucianism is one of the most significant Eastern philosophies and has influenced East Asian society for more than two millennia. It has entirely permeated the way of life of people in East Asian societies. In other words, it has played an important role as both a conscious political ideology and a "taken-for-granted" everyday social ethic. Indeed, this fact also explains its capacity to permeate everyday life. Education, family structure, government and the general values of East Asia have been affected, to varying degrees, by Confucianism (Roetz, "Confucianism and Familism" 41). Although it would be an exaggeration to state that all conventional life and culture of East Asia are Confucian in a narrow sense, to a significant degree, Confucianism can be used in a broad sense as a label for East Asian culture.

As Ronald indicates, Confucianism is "a code of ethics for family and social life based on filial piety, [which] is strongly integrated into household and family practices" (56). Confucius believed that filial piety should be regarded as a primary form to arrive at the moral excellence of humanity (Yong Huang 6), and argued that personal dignity can be enhanced by cultivating genuine feelings for one's parents (Tu, "Confucius and Confucianism" 13). Confucius thought that family was of greatest significance because human beings could learn fundamental virtues through it (Roetz, "Confucianism between Tradition" 369). For Confucianism, "the first test for our self-cultivation is our ability to cultivate meaningful relationships with our family members" (Tu, "Confucius and Confucianism" 13 ). The fundamental Confucian virtue of humanity (ren, 仁) ${ }^{4}$ is the ultimate product of self-cultivation. In Confucius' writings, the most significant and distinctive elements in the father-son 
relationship are those concerned with the absolute obedience and respect of the son for his father. While it is argued by Tu that the son should encourage and nurture himself, he must also learn self-control, and subsequently be able to overcome feelings of desire, recognize the requirements of his father, and regard with reverence his father's requests (Confucian Thought 115).

We can thus summarize the concern for filial piety through a series of questions: What is filial piety? Why is the concept of filial piety particularly important in East Asian culture? What are the political implications of filial piety? And crucial to this paper-is it possible to criticize filial piety from a standpoint that transcends East Asian culture, and in so doing, reconstruct the basis of political authority in that culture?

In East Asian culture, the concept of filial piety (xiao, 孝) has a deep, long, and complex history. The family is considered to be society's individual organizing element, and the ethics associated with filial piety, particularly in relation to Confucianism, has ultimately developed into the distinguishing element of the moral identity of Eastern culture. As a result, the ethical standpoints concerning Confucianism penetrate every level of life within the societies of East Asia (Kunio 110). From the perspective of Confucius, the notion of filial piety formed the initial element in the process of achieving an ideal moral character. In Book II of the Analects, there are four passages in which Confucius explains to his disciples the definition of filial piety:

When your parents are alive, serve them according to the rule of propriety. When they die, bury them according to the rules of propriety and sacrifice to them according to the rules of propriety. (Lau, Analects 2.5)

Give your father and mother no other cause for anxiety than illness. (Lau, Analects 2.6)

Nowadays for a man to be filial means no more than that he is able to provide his parents with food. Even dogs and horses are, in some ways, provided with food. If a man shows no reverence, where is the difference? (Lau, Analects 2.7)

What is difficult to manage is the expression on one's face. As for the young taking on the burden when there is work to be done or letting the old enjoy the wine and food when these are available, that hardly deserves to be called filial. (Lau, Analects 2.8)

We can take from these injunctions that Confucius regards filial piety as not just ensuring the provision of ritual burial and materialistic requirements. In other words, filial piety and its overall practice should not be considered as merely 
ritualistic, but rather as guiding action in everyday life, and those who practice filial piety should be sincere in the performance of their filial duties.

In the context of East Asian culture, Confucianism is distinctive such that great emphasis has been placed on the role of the family. The family is never a subordinate element of political life, nor can it be transcended. As Jordan contends, the concept of filial piety in Confucian culture is a central concern in all thinking about moral human behavior:

Filial piety is simultaneously (and ambiguously) both a mental state and a behavioural code, and the behavioural code is (also simultaneously and also ambiguously) both a set of actions and a system of values underlying those actions. Thus we find that filial piety in Confucian culture may be defined in three quite separate ways: (1) filiality as action directed toward a parent and exhibiting submission and nurturance; (2) filiality as an emotion of love toward a parent that is understood to differ from other sorts of attachment (filial piety as emotion is particularly vivid in the context of funerals, which provide strong cultural support for this interpretation of a mourning child's affect); (3) filiality in children as part of a system of values, which must be self-consciously cultivated. $(271-272)$

Filial piety in Confucian culture provides the foundation of emotional love and faithfulness of children to parents, but it also generates an authoritarian social structure in which social relations are fundamentally hierarchical. With filial piety, hierarchical relationships exist across generations, and there are permanent obligations of respect, reverence, and obedience. It bestows a privileged position not only on the older generation over the younger generation and the parents over the children, but also the male over the female, since the obligations are directed toward the father. Thus, filial piety is also patriarchal. As Liem argues, filial piety maintains the "emotional link between recollection and trans-generational inner reality" (75). Filial piety has played a fundamental role in the society of East Asia as a way of guaranteeing both ontological security-meaning it provides a sense of self or personhood-and general social hierarchy (Hashimoto 196). The importance and influence of filial piety in East Asian societies are undisputed characteristics, and its consequences are also unmistakable. Therefore, it can be stated that the notion of filial piety has been utilized as a means of achieving progress in terms of Confucian culture, spanning numerous generations. In addition, filial piety and its practices have formed a way of life in Confucian culture and have ultimately stipulated the rules and expectations in terms of power and duty between children and parents, which then further support and reinforce the societal hierarchy present in the Confucian societies of Eastern Asia. 
A concrete illustration of filial piety in South Korea would serve as a good example of how, in Confucian culture, the practice of filial piety plays out as a dominant political ideology. Filial piety can be viewed from two perspectives: empirically, as a "lived practice," and ideologically as a body of thought which reflects upon that lived practice and seeks to justify it. That justification focuses both on the immediate relationship between parent (primarily the father) and child, and on the wider social and political role of filial piety-specifically its role in justifying political authority. The focus of this paper is mainly on filial piety as ideology, because it is concerned with the reasons we give one another. This is central to the debate between Gadamer and Habermas, but it is also important to recognize that filial piety is a real, lived experience in East Asian culture, albeit one that is subject to change and reinterpretation over time.

There is no simple or straightforward relationship between practice and ideology because ideology is a form of practice. This idea of filial piety as ideology is illustrated by the development of the "Filial Piety Prize" in South Korea. This prize was established by the Ministry of Health and Social Welfare in 1973 and is awarded annually to about 250 people who are nominated by their local community or a private organization (Sung and Song 37). In 2008, the "Act on the Encouragement and Support for Filial Behavior" was enacted in 2007 and came into effect in August 4, 2008, in order to promote good cultural heritage of filial piety at the national level in South Korea. The Ministry of Health and Social Welfare of South Korea awarded the Filial Piety Prize to 130 people on Mother's Day in 2016 (Lee 179). According to Sung and Song, the purpose of the prize is twofold: "To preserve the value of filial piety as a cultural heritage of the nation, and...to stress the importance of the practice of filial piety, the idea of parental care, in order to impede the decline of elderly care" (37). The latter rationale would not be unfamiliar to Western observers, for the more support members of a family provide for one another, the less reliant they are on state spending. However, the effectiveness of the prize depends on a background set of values which are non-Western.

Sung and Song undertook a content analysis of the "stories" that accompany each prize. In effect, the stories are the explanations for why a prize was awarded. They grouped the reasons together and found that in $85 \%$ of the stories "showing respect for parents" was indicated, followed by "fulfilling filial responsibility" (84\%), "repaying debts to parents" (71\%), "harmonising the family" (46\%), "making filial sacrifices" (43\%), "showing filial sympathy" (26\%), "maintaining family continuity" (20\%), "compensating for undone services" (10\%), "providing services to other elders" (6\%), "complying with religious teachings" (5\%), and "maintaining family honour" (5\%) (43). Some of these beg further questioning: "Filial responsibility" and "filial sacrifice" presuppose that the public knows what is meant by the term "filial." The overall point is two-fold: on the one hand, the need to institute a prize 
would suggest that filial piety is in decline, but the possibility that the prize could be effective suggests that the Korean state thinks that the practice still has sufficient force for it to motivate people. Clearly, this is an ideological manipulation of an ancient practice.

\section{THE REINFORCEMENT OF POLITICAL AUTHORITY BASED ON FILIAL PIETY}

It is certainly possible that two different forms of relationship exist: one that is harmonious and equal, and another, which is hierarchical and inegalitarian. While the former assumes that a non-conflictual relationship can exist between individuals, the latter inevitably entails conflict. To a certain degree, human relationships necessarily involve some idea of equality, or at least of mutual dependence. The fundamental issue is whether there is a deeper moral equality, and how that moral equality fits with the hierarchy of Eastern culture, underpinned by filial piety. In the case of Western culture, the performance of filial piety-insofar as we can say that the phenomenon exists in the West-is built on personal choice, as opposed to obligations and duties, which is applicable to both children and parents. On the other hand, there is much emphasis placed on obligations and duties in an Eastern context. In the West, filial piety is potentially a threat to personal autonomy. From a Western perspective, the practice of filial piety in Confucian culture is viewed as detrimental to the pursuit of individuality and personal autonomy, and it cannot fully guarantee equal rights (Yusheng Huang 40; Fan 516).

The ultimate core of filial piety is apparent in those children who illustrate "absolute obligation with regard to their parents, an obligation that trumps all other demands and moral concerns" (Ivanhoe 197). The formation of the traditional family in Confucian culture stems from a hierarchical social structure (Slote 39 ) in which ultimate authority rests with the father and husband. In this sense, parents (especially the father) have an all-powerful and all-fulfilling authoritarian potency, and their authority finally leads to "fear, dependency, and hostility" in the Confucian family system (Slote 46). Filial piety is not only concerned with gratitude and kindness, and subsequent debt and obligation, but also encompasses acknowledgement of the fact that kindness was awarded by someone in a much more powerful position. Such a notion can help to achieve a deeper level of understanding of why those who follow the tradition of Confucianism regularly state that filial piety is the most natural model in determining the best relationship between subject and ruler, or child and parent (Ivanhoe 196-197).

The level of consciousness surrounding the notion of filial piety in East Asian Confucian societies complements the hierarchical relationship and social structure 
within society to a certain degree. The Classic of Filial Piety ${ }^{5}$ (XiaoJing, 孝經) is one of the key documents in the advancement of filial piety as a broader means of reinforcing social hierarchy. The book comprises a compilation of key accounts of the practice of filial piety with the aim of emphasizing and reiterating the Confucian ethics associated with filial piety. This is done with the overall objective of contributing to and developing the level of education within those East Asian countries adopting the Confucian tradition. It is noteworthy that for Confucius, the application of filial piety is not restricted to private or individual virtues, which can only be practiced within family institutions. For example, in the Analects, the concept of filial piety is considered to be the source of the moral character exemplified by persons within the political sphere:

It is rare for someone who has a sense of filial and fraternal responsibility to have a taste for defying authority. And it is unheard of for those who have no taste for defying authority to be keen on initiating rebellion. Exemplary persons concentrate their efforts on the root, for the root having taken hold, the way will grow therefrom. As for filial and fraternal responsibility, it is, I suspect, the root of humanity (ren, 仁). (Lau, Analects 1.2)

Therefore, in the familial sphere, filial piety is considered to be the ultimate foundation for one's own moral capacities in the political sphere. Of course, filial piety is predominantly directed to an individual's own parents. However, the general arena of filial piety ultimately reaches far beyond the family sphere and advances to that of the state. Filial piety as outlined in The Classic of Filial Piety is implemented by aiding one's own parents in the familial sphere, but in so doing one emphasizes one's ancestry, and this results in dedication and service to the state. As highlighted by Chai and Chai, both political and social duties and the tradition of ancestral adoration in East Asian tradition are combined to form a key doctrine (326-327). In sum, it should be acknowledged that filial piety may be considered an initial education for what is to follow when serving the state in East Asian Confucian societies.

The Classic of Filial Piety introduces the key idea that filial piety is the ultimate root of all that is great; therefore, any person who embodies the qualities associated with filial piety would ultimately also encompass all other beneficial qualities and virtues (J. Liu 77). Thus filial piety extends to the political arena, so that serving one's royal monarch is also included as one strives to fulfil filial obligations. Filially pious behaviors must, therefore, be divided into stages: The notion of serving one's own parents is only the first stage of several. It is ultimately required that an individual provides his or her parents with pride and joy through by one's own monarch, which is the only way in which filial obligations can be satisfied (Bellah 93-94). 
The Classic of Filial Piety may have extended the concept of filial piety to serving one's monarch in order to resolve the conflict between loyalty to one's parents and loyalty to the state. It is noteworthy to state that, when acting in the role of government official, an individual is ultimately required to adopt two different identities - that of a son and that of a subject. The father holds the position of highest authority within the family structure, so that the son is therefore required to obey him; however, the monarch supersedes all in this hierarchy. The amalgamation of the political ethic of loyalty in combination with filial piety as a familial ethic has a significant impact on the monarch-minister relationship in terms of its development, which is now seen as being unequal and one-sided. The method and subsequent progression of filial piety has been described in The Classic of Filial Piety:

The Master [Confucius] said: "The gentleman serves his parents with filial piety; thus his loyalty can be transferred to his sovereign. He serves his elder brother with brotherly deference; thus his respect can be transferred to his superior. He orders his family well; thus his good order can be transferred to his public administration. Therefore, when one cultivates one's conduct within oneself, one's name will be perpetuated for future generations." (XiaoJing 15b-16a)

The important concept here is "transference." Filial piety must be made compatible with loyalty to the state, which means that the concept does not simply extend to the ruler-subject relationship but actually redefines it (Chow 304). From the perspective of a minister, filial piety could act as a substitute for loyalty and vice versa (Jung 134). However, when there is any form of discrepancy between the two elements - that of loyalty and filial piety-a minister would ultimately seek to achieve loyalty, which would subsequently be considered as fulfilling his obligations in a filial context (Hamilton 98). In the Classic of Filial Piety, the basis for imperial rule in relation to Confucian societies in East Asia was laid down by the interpretation of the link between filial piety and loyalty. Moreover, in the Classic of Filial Piety, the overall idea underlying filial piety was amended and shaped so as to conform to changes in the monarchical systems. In other words, Confucian societies' rulers utilized the ethic of filial piety in order to encourage and foster the overall objective of supplementing common people's education.

The ultimate principle of Confucian filial piety has critically encouraged and emphasized the doctrine of transference of filial piety to loyalty-that is, those who strive to follow filial piety toward their parents will similarly show loyalty to their ruler. Furthermore, if an individual adopts filial piety and serves his parents, it is then required that such loyalty be replicated to serve the monarch. The monarchs of Confucian societies attempted to affirm their persona as Confucian sage kings and accordingly encourage loyalty and corresponding duty (Cheng 55-56). It was claimed that they were communicators of the sages, and they subsequently 
determined their own standing as sage rulers while solidifying the overall political interpretation of ensuring loyalty above filial piety. With this in mind, it can be stated that the transference to loyalty from filial piety has been adopted in order to further encourage and strengthen the idea of loyalty to the monarch at the expense of filial piety (Cheng 63). Accordingly, filial piety has undergone promotion and encouragement within an imperial context, with the effect that filial piety has been politicized (Hwang 175-176). This raises a problem: Is loyalty to the ruler more important than filial piety of child to father? If we say that filial piety is the most fundamental form of obligation, does that undermine loyalty to the ruler? One answer is to treat filial piety as "ideological," in the sense that rulers (or their theorists) have taken a deeply rooted cultural practice and sought to draw on it to justify political power. The other might be to argue that what is "fundamental" and what is the "highest duty" are two different things. Filial piety is fundamental in that it is the most basic relationship, but political loyalty entails a higher-level relationship. In any conflict between the two, loyalty to the ruler is ultimate.

In this context, attention should be drawn to the doctrine of filial piety in the Three Bonds (Sangkang, 三綱), ${ }^{6}$ which demonstrates that the hierarchical relationship is an inviolable ethical norm by means of which the Confucian social order is preserved. The essence of the Three Bonds is that "the minister serves the king, the son serves the father, and the wife serves the husband. If the three are followed, the world will be in peace; if the three are violated, the world will be in chaos" (Tzu 75). The logic of the Three Bonds is therefore concerned with ensuring ruler authority over ministerial authority—-father over son, and husband over wife. Paternal authority is fundamental, but ruler authority is higher. In consideration of the Three Bonds' doctrine, ensuring the authority of the father over the son is considered to be the most fundamental of all elements with regard to the concept of filial piety. Hence, filial piety is the ultimate basis for all qualities and virtues in the Confucian tradition.

As seen in the Confucian texts, the demanding force of propriety in Confucian tradition establishes the familial structure by bestowing the dominance of parents over children and husbands over wives. This form of dominantsubordinate relationship has ultimately shaped the social and political structure of authoritarianism in East Asian Confucian societies. Of course, there is nothing wrong in either culture with ensuring the loyalty, compliance, and respect of young children towards adults, but it is evident that an authoritarian family structure determines the obedience of children to the parents, as elaborated by the practices of filial piety. As a result, the notion of filial piety is also applicable to those who have reached the "age of reason," or adolescents. Indeed, it could be argued that a child has to reach a state of maturity in order to grasp his or her duties. In this context, an issue might arise if children are to obey their parents absolutely even 
if parents should wrongfully exercise their authority over their children, or indeed if the parents should violate moral, social or legal rules. Put concretely: Should a child cover up the crime of a parent? As Rosemont and Ames asserts, Confucian "role ethics" is dependent on the pursuit of cosmic harmony in order to sustain the existing familial and communal order. This means that the father-son relationship should be maintained by emphasizing filial piety rather than drawing attention to the actual human conduct, even if this means that a son ignores his father's crimes (17). It is clear that the main aspect of filial piety is blind obedience of children to parents.

The underlying ethic of filial piety is deeply rooted in the ability of children to repress antagonistic attitudes toward their parents (Yim 165). As Slote claims, the core of "Confucianism was based upon authoritarianism, and filial piety was the principal instrument through which it was established and maintained .... it has been, in fact, the modus through which the Confucian hierarchical relationship was maintained" (46). Confucian societies primarily appear to be shown as having a hierarchical structure, socially and politically, that is underpinned by yielding authority to one's parents (particularly the father). The Confucian ethic of filial piety has created a "model person," or an "ideal type," in seeking filial obligation to one's parents as well as the monarchy. The relationship between parents and children, based on the Confucian ethic of filial piety, has required the blind obedience of children toward parents. As far as filial piety is concerned, it has served as the socio-political basis of Confucian culture. Considering claims about the moral status of filial piety, the primary aspect of filial piety is the absolute obedience of children to parents; following this traditional idea, the ethic of filial piety has served the political requirements of societal order in Confucian East Asian culture. Accordingly, political control of the parent-child relationship, based on the prominence of filial piety, reinforces the consolidation of authoritarian values. In this sense, the relationship between parents and children should be reconsidered. Filial piety is ultimately a discourse that diminishes the power of the children in the interest of safeguarding the hierarchy of social difference. It effectively regulates the interests of the children by assigning obligations and debt to them. Subsequently, democratic and individualist rules of engagement are seemingly necessary to buttress the autonomy of individuals. In other words, instead of acknowledging the inequality of individuals based on the authoritarian relationship between parents and children, we need to guarantee free and autonomous individuals who could have equal rights.

Drawing upon Zhou Dynasty culture, Confucius claims that "it is not till a child is three years old that it is allowed to leave the arms of its parents. And the three years' mourning is universally observed throughout the empire" (Lau, Analects 17.21). The core value of filial piety of the ancient Chinese culture and 
Confucian virtue ethics itself might offer a positive outlook in that parents' unconditional love of their children is a universally humanistic emotion, and that children's unconditional respect of their parents is also rational and humanistic. In this context, the conceptual aspect of filial piety could play a positive role in the conceptual system of Confucian virtue ethics.

The arguments surrounding Gadamer and Habermas' different philosophical epistemologies are plentiful. Furthermore, many studies have mainly discussed the central concepts and general philosophical differences between the two philosophers. However, no study has tried to investigate the concept of filial piety of Confucian culture in East Asia with respect to the philosophical debate between Gadamer and Habermas. This study initially intends to scrutinize a concrete and practical illustration of the practice of filial piety in Confucian East Asian culture by examining the abstract philosophical discussions of the two philosophers. Moreover, this paper applies the overly written Habermas-Gadamer debate on the Confucian practice of virtue ethics of filial piety. It is attentive to Confucian East Asian culture, which values filial piety and extends the concept to socio-political realms. Its primary emphasis is in recognizing the negative points, by focusing primarily on the factual aspects of filial piety in the current Confucian East Asian culture. Thus, the paper not only observes the negative effects of the factual aspect and actual practice of filial piety in the ways in which it is totally distorted in the contemporary Confucian East Asian culture, but it also provides a constructive critique of the practice of filial piety embedded in the conceptual scheme of Confucian virtue ethics.

The debate between Habermas and Gadamer is not between a defence of patriarchy versus egalitarianism, but over the role that traditions of patriarchy play in justifying political authority. Gadamer is not defending patriarchy but tradition, which in the case of East Asia draws on filial piety. The problem of how we define the status of filial piety will be of importance in understanding filial piety-and more broadly Confucianism - as "tradition" in the debate between Habermas and Gadamer.

\section{GADAMER'S APPRECIATION OF TRADITION WITH RESPECT TO THE CONCEPT OF FILIAL PIETY}

Richard Palmer argues that there are some affinities ${ }^{7}$ between Gadamer and Confucius or Confucianism (81-93). Allowing for differences in language and tradition, he argues that there are parallel concepts in the work of the two thinkers, such as "truth, textual contemporaneity (Zeitlichkeit), phronesis, application, 
tradition and the historically-effected consciousness, ${ }^{8}$ conversation/dialogue, and solidarity" (83). The guiding concept is tradition (Palmer 91). Just as Gadamer stresses the importance of tradition as a precondition for human existence in a particular culture, Confucius also considers the concept of tradition of significant importance in Confucian societies. For Gadamer, tradition is important both for epistemology and morality. The intention of his research scheme, "philosophical hermeneutics," is not to scrutinize how understanding occurs in the human sciences, but to consider understanding relative to the entire human experience of the world (Truth and Method [1989] xxiii). According to Gadamer, the notions of understanding and interpretation are intertwined, and a tradition is a horizon of understanding. Tradition equips the subject with the necessary conditions of understanding; they are what Gadamer terms "prejudices."

We can see parallels in Confucius. Gadamer argues that tradition is of importance because it carries "superiority in knowledge and insight" (Truth and Method [1989] 279). Following the Gadamerian notion of tradition, Alan Chan asserts that Confucian ethics entail "finding in tradition a reservoir of insight and truth" ("Confucian Ethics" 245). In the Analects, Confucius explicates the idea of tradition: "I transmit but do not innovate; I am truthful in what I say and devoted to antiquity" (Lau, Analects 7.1), and "I am not one who was born with knowledge, but one who is fond of antiquity and quick to seek it" (Lau, Analects 7.20). In this context, Confucius employs the concept of the Way (Dao, 道) and argues that people should follow the Way as they follow tradition. For Confucius we should trace and follow the knowledge, wisdom, and insight largely derived from the experience of the past and embedded in tradition. In so doing, we can learn the Way as a practice, which we take for granted, as a means of employing the conventional understanding and knowledge formed by tradition. In Confucius's view, understanding and knowledge can only be practiced within the context of tradition. With reverence for tradition, individuals pursue the tenet of the Way and can easily grasp the teachings of Confucian filial piety:

It is natural enough to take the idea of filial piety as a component part of the [East Asians] respect for tradition....the idea of filial piety as obedience to the father can be taken to refer to the necessity to stand within a tradition in the seeking of wisdom and knowledge. Disobedience, in turn, can be taken to refer to the disregard of tradition, or traditional knowledge....to have filial piety is to have understanding of the tradition handed down by the fathers, and to have the appropriate fore-knowledge for the acquisition of knowledge and wisdom. One must acquire a perspective by immersing oneself in one's tradition before one can embark on the task of interpretation and understanding.... [to be] a person with a certain level of understanding, a person with humanity (ren, 仁), one has to learn the way of the fathers, the way of tradition, or simply the Way. In other words, we could assume that filial piety means much more than just

Kritika Kultura 33/34 (2019/2020): 49-064

(C) Ateneo de Manila University

<http://journals.ateneo.edu/ojs/kk/> 
to follow the instructions of one's immediate parents; it means to follow the tradition, the Way. Thus, in Chapter 29 (29.1) of the Xunzi, we find: "Inside the home to be filial.... and outside the home to be courteous....constitute the minimal standard of human conduct....To follow the dictates of the Way rather than those of one's father constitute the highest stand of conduct." (Xunzi 29.1)

As Palmer argues, Gadamer and Confucius have a similar view of the use of the concept of tradition (81). Confucius considers tradition to be a source of "insight and truth" (Chan, "Confucian Ethics" 245), and like Confucius, Gadamer defines tradition in terms of human self-understanding. Tradition, for Gadamer, is the carrier of a "superiority of knowledge and insight" with regard to truth (Truth and Method [1975] 280). The ethic of filial piety likewise requires the obedience of children to parents within the context of a tradition, which underpins their parents' knowledge and wisdom. According to Gadamer, tradition determines our being and understanding; it is expressed in and through our "prejudices," and it provides a horizon from which we may view the world. Indeed, human beings must necessarily operate with a "tradition of traditions" (Truth and Method [1975] 261). In the sense that we can shape tradition, we are free; certainly, tradition sets limits, but tradition presents us with options or choices. Every tradition is thus a "living tradition" - that is, continually changing and adapting. Accordingly, history is not the "no longer existing," but rather, past and present are mutually entangled through the notion of self-understanding.

In Gadamer's view, tradition serves as the ground for understanding. If tradition is that which moulds and directs our perspectives, then understanding is a "fusion of horizons" (Truth and Method [1989] 302). Such a notion demonstrates that we are never separate from that which we strive to understand. Furthermore, for Gadamer, to live and to be is to stand within tradition. All understanding is grounded in tradition, and the idea of the "fusion of horizons"-which remains central to historical understanding-can ultimately only result from a meditation upon tradition. Tradition is an ongoing process of the fusion of horizon of the present and of the past. Gadamerian analysis of the fusion of horizons appears to be that the "horizon of the present is continuously in the process of being formed," as we continually test our prejudices in our encounter with tradition. Our prejudices are the product of history, so that studying history-understanding our tradition-is a critical process. This shows the falsehood and naïveté of an isolated formation of a horizon of the present without recognizing or acknowledging the necessity of knowing tradition (Gadamer Truth and Method [1989] 306). Along with Gadamer's emphasis on tradition serving an important role in human society, tradition is grounded in "prejudices." While prejudice forms the basis of tradition, the totality of tradition is itself the means by which we evaluate, or criticize, our prejudices. There is therefore a feedback mechanism between prejudice and 
tradition, making tradition a critical tool, but one that is not "abstract." It is not a "view from nowhere." This is important when we seek to understand East Asian culture and, specifically, filial piety. . It allows us to differentiate between filial piety as an essential element of social order and the language of filial piety as a mere instrument of domination. If we take obedience to parents to be a prejudice, then we can assess that prejudice, first, by locating it within the tradition of filial piety. Second, we assess filial piety with a broader Confucian culture. Filial piety is part of that Confucian culture, but that culture simultaneously allows for a distinction between legitimate and illegitimate exercises of parental power.

Such a form of moral understanding, which is present in the concept of Confucian tradition, seems also to be a characteristic trait of the Gadamer's notion of tradition. In this sense, it is easy to see how one is able to reach an understanding of tradition from the perspective of Confucius. The notion of tradition could be considered as the ultimate root of the moral teachings of Confucius. As Chan argues, the overall function of tradition, especially in consideration of Confucius' Analects, "lies in its mediating position between Dao as the will of Heaven and Dao as the way of [the true gentleman] (Chün-tzu, 君子)" (“Philosophical Hermeneutics" 430). According to Confucius, Confucian hermeneutics thus emphasizes the Way as a means to maintain tradition. $\mathrm{Ng}$ argues that learning and following "the Dao is to realize the moral and ritual order established by the ancient sages" ("Chinese Philosophy" 378). Compliance with the Way is a prerequisite for the recognition of norms and values, which are shaped by tradition. In Confucian tradition, therefore, the practice of filial piety is the fundamental basis that ensures norms and values grounded in the employment of moral and practical exercises. In so doing, filial piety furnishes self-understanding of one's own tradition, based on conventionally inherited wisdom and knowledge; its practice functions as a conventional norm, which conforms to existing tradition. Thus, both Gadamer and Confucius have a shared understanding regarding "tradition," which plays a significant role within the context of human existence. The concept of filial piety has been recognized as central to East Asian culture and has been a tool for the ruling ideology of Confucian societies in East Asia. The teachings of Confucius essentially reflect a "conservative" orientation. Thus, it can be said that Gadamer's thesis is also conservative, and there is a fairly similar stance between Gadamer and Confucius in terms of the importance and interpretation of tradition. While Gadamer places focus on tradition, Confucius places importance on the custom of antiquity. Confucius recognizes the ethical principles embedded within tradition, while Gadamer appropriates the significance of tradition.

Gadamer argues that the most important role of philosophy lies in the understanding of the ontological nature of human existence-that his primary philosophical inquiries depend on the understanding of the human being in 
relation to its finite existence. According to Gadamer, the civilization of human beings would not have been preserved without the force of tradition, and the claim of tradition could embrace the ideological distortion of overarching prejudices at all levels. In other words, all human activities could be interpreted from within a tradition in explicating the understanding of the ontological nature of human existence, so that even the ideological distortion can be subject to tradition. In short, Gadamer defends the force of tradition as positive in emphasizing that every aspect of human understanding is ultimately connected to tradition and determined by it ("Reply" 288).

\section{HABERMAS'S CHALLENGE ON GADAMER: CRITICAL OBJECTIONS TO THE CONCEPT OF FILIAL PIETY}

Although Habermas and Gadamer agree that reaching an agreement is at the heart of resolving both practical and epistemic conflicts between individuals, they differ on the issue of how an agreement between interlocutors is achieved. Both Gadamer and Habermas emphasize dialogue, but the importance that dialogue plays for each of them is significantly different. Gadamer sees dialogue as a way of coming to an agreement between partners. It involves thinking about how interlocutors may reach an understanding of the subject matter at issue. However, his emphasis on dialogue lacks a methodology on how to communicate-that is, criteria for successful communication-as well as a regulative ideal of dialogue, or a conception of rules constraining dialogue. His philosophical hermeneutics simply scrutinizes the basic existential structure of human existence (Dasein), concentrating only on the disclosure of "Is," rather than placing in question the "Is" by reference to normative standards ("ought"). On the other hand, Habermas's position on communication sets out what is required for a conversation, such that dialogical partners are oriented to arrive at a counterfactual understanding of what is at issue.

In Habermas's account, reaching understanding is a process of reaching agreement "among speaking and acting subjects" (The Theory of Communicative Action 286). According to Habermas, communicative action pertains to action oriented towards reaching an understanding. His primary concern is to establish coercion-free communication. With communicative action, relations can be established between actors who are able to speak and act so to achieve mutual consensus. Here, we can see how Habermas links reasons and actions through the medium of language. The concept of communicative rationality, he argues, depends primarily on the "consensus-bringing force of argument speech," in which participants overcome their subjective points of view and reach mutual 
understanding based on rationally motivated agreement (Habermas, The Theory of Communicative Action 10). Thus, the participants (speakers and hearers) can ultimately attain uncoerced, unifying consensus. In Habermas's account, the goal of speech is to arrive at an understanding between conversational participants who can coordinate actions in order to reach agreement through intersubjective and reciprocal communication between a speaker and a hearer. Habermas considers that the meaning of an utterance is fundamentally a shared understanding between a speaker and a hearer-not "shared" in an instrumental sense, but shared based on a presupposition of equality between speaker and hearer. Without this recognition of equality, a theory of meaning would be reduced to a conflict between participants (Finlayson 38). In Habermas's view, reaching understanding is thus an impossible task, unless there is consensual agreement of participants in communication with regard to a particular object, rule, or state of affairs.

The mutual understanding between the speaker and the hearer serves as the basis for Habermas's communicative action theory. However, a problem concerning the lack of mutual understanding between the interlocutors, parents and children, arises when the filial piety of Confucian East Asian culture is put into the context of Habermas's communicative action theory. In this particular situation, the speaker (parents) can force a conversation onto the hearer (children), and the conversation may turn into a verbally mediated exercise of power-that is, unequal communication on the basis of excessive authority of parents over children, rather than one of genuine communication, as Habermas claimed. In addition, the weaknesses of Gadamer's explanation of communication, and the corresponding strengths of Habermas's position, can be illuminated in reference to filial piety. Without a methodology to assess valid speech and normative rules regulating speech, we are incapable of coming to a judgement over the legitimacy of personal-and, importantly, political—relations grounded in filial piety. Filial piety powerfully illustrates the difference between Habermas and Gadamer: without criteria for assessing valid and invalid speech, any kind of power relationship, however oppressive, can be subsumed under "filial piety."

The Confucian virtue of filial piety, which requires reciprocal care between parent and child, is our starting point for being human (Q. Liu 236). Such a relationship is not unique to the East. To be sure, there are Western conceptions of the family as a moral entity. However, what distinguishes the Confucian ideal is the subordination of the child to the parent. Confucianism emphasizes authority over liberty and responsibility over rights, but it lacks the tradition of an individual's claim of rights against the state, which would counterbalance parental authority. In other words, if the practice of communication between parents and children is mainly dependent on parents' excessive dominance over children in order to keep parents' illegitimate authority, then this kind of speech act might not be carried out 
as a reciprocal understanding between them. In this sense, it is evident that mutual understanding based on a rationally motivated conversation between actors (parents and children) in speech situations seems to be an impossible mission. Moreover, an exercise of lopsided coercion of parents' authority over the children might damage the intersubjective understanding between parents and children. Hence, Habermas's theory of communicative action can serve as reasonable ground on which to transform the problems raised by filial piety. It is important to underline that filial piety is not merely a relationship between child and parent and thus part of the private sphere, but it also underwrites political authority.

In general, critical theory is not merely concerned with describing social reality, but it also seeks to synthesize a respectable description of social reality with a critical or normative ideal. Critique can be achieved through the very notion of criticism: by standing back from existing practices and refusing to accept the normativity of what is "given," the critical theorist presupposes a standpoint of "ought" in the face of "is." Questions of normativity are only ever posed when what exists is no longer taken for granted. As Wellmer argues: "An ethical question first exists when the agreements of actions with the factually valid norms of a society are no longer recognized as the final instance of a 'justification' of these actions" (293). And as Habermas suggests, we should differentiate between social norms which are justified by nothing more than an appeal to de facto social norms, from social norms which are legitimately and reasonably valid (The Theory of Communicative Action 287). The idea of a critical social theory has at its core a fundamental tension, which is derived from the intention of critical social theory to generate a rational critique. The outcome of such a justificatory process should ultimately be rational, simply because it is fundamentally built on reason. The idea is that any social agent who has any ability to speak or act would ultimately be rationally convinced of the rightness associated with justifying the norm (Held 330). The outcomes of rational justification processes are acceptable if the processes by which they were arrived at are universally valid (Hoy and McCarthy 172-173). Thus, Habermas seeks to "shake the dogmatism of life-practices" (The Theory of Communicative Action 357 ) by means of critical reflection whereby human beings can defy tradition. In his view, Gadamer underestimates the power of critical reflection (Mendelson 59). He argues that Gadamer's recognition of "prejudice for the rights of prejudices certified by tradition denies the power of critical reflection" (Habermas, The Theory of Communicative Action 237). In this sense, it is worth noting that we might be able to rule out and reject the unjust or illegitimate tradition, which is fundamentally grounded on "systematically distorted" dogmatic forces. Thus, tradition could be transformed by means of employing the power of critical reflection.

As I have explored earlier, Confucius and Gadamer have a shared understanding in which tradition should be understood as the appropriation of norms and values 
embedded within existing tradition. For Habermas, a Gadamerian "justification" of filial piety is in effect an ideological reinforcement of existing power relations. Gadamer is, in a negative sense, a conservative. As Chan points out: "Confucius can be described as a 'conservative' thinker in the technical sense that he regards certain values and insights derived from tradition to be of normative significance, and which must therefore be carefully conserved" in urging us to follow the wisdom of antiquity ("Confucian Ethcis" 246). Even Warnke who appropriates Gadamer's philosophical standpoint claims that Gadamer is, "fundamentally conservative" in that human agents cannot overcome the authority of tradition to which they belong (136).

Having reviewed the textual evidence of Confucianism, it can be stated that filial piety has served as a resource for sustaining the hierarchical family structure of East Asian Confucian culture. It is noteworthy that filial piety cannot be diminished or lessened so that it is merely duty; ultimately, it is an important virtue in its own right. As has been previously emphasized, the relationship between parent and child is not balanced nor equal, which is what makes filial piety the perfect model when implementing a relationship with a ruler-subject nature (Tan and Chan 8). As Sor-hoon Tan maintains, the idea of filial piety "is fraught with patriarchal and authoritarian prejudices and would thus require reformation if it were to contribute to the development of [Confucian East Asian] culture" (2-3). Thus, viewed from a Habermasian perspective, filial piety is a case of ideological distortion. In particular, the patriarchal relationship between the superior and inferior suggests that there is an unequal relationship. In this regard, Habermas's pronouncement of impartial adjudication of conflicting rights claims is more relevant than Gadamer's seemingly uncritical acceptance of tradition.

The concept of filial piety presupposes inequality between parents and children in Confucian East Asian societies. In this sense, the relationship can be judged as not merely unjust in an intuitive sense, but also irrational and unfair. If we follow Habermas's argument, then the role of communicative competence relies on the consensus between individuals who are committed to reach an understanding. The assumption of this ideal speech situation lies in rationally conceived action among individual participants to reach an understanding. Habermas's model of communicative competence with regard to the example of filial piety seems suggestive, because it conceives of the equal and autonomous intersubjective relationship between two parties-the parents and the children-as primarily based on rational action. Without an actual consensual relationship between the two parties, as Habermas argues, it is likely to become a monological relationship rather than a dialogical one among communicating individuals. 


\section{CONCLUSION}

This paper explores the debate between Gadamer and Habermas associated with the practice of filial piety in Confucian East Asian culture. While Gadamer acknowledges tradition and authority as the unavoidable human condition given the finitude of human existence, Habermas criticizes Gadamer's ontologicalexistential position by demanding an exercise of reason-or critical reflection. Upon such critical reflection, according to Habermas, illegitimate tradition can be overcome. It is argued that Habermas's communicative action theory is better able to do justice to the basis for the normative grounding of authority, so that it endorses Habermas's charge that Gadamer hypostatizes tradition.

Gadamer does produce a strong impression of conservatism in his defence of tradition, which it exercises over us-a point that Habermas quickly raises against Gadamer. Is all tradition welcome? Is all tradition truthful and acceptable? Certainly, these are questions that any reader of Gadamer could raise legitimately, but more so Habermas who would see in tradition the source of prejudice and ideological beliefs (Habermas, "On Hermeneutics" 316; Habermas, Logic of Social Science 168). We can apply these questions to filial piety. Children find themselves "thrown into" a culture and cannot choose it, but there may be scope for criticism if they believe that their father is not acting within the tradition but abusing it. This requires, on the part of children, an analysis of the conditions of the practice of filial piety. In essence, the child asks: does filial piety require that I obey this order? If my father commits murder does filial piety require that I conceal the crime? Since filial piety is connected to wider social and political duties, it is likely that a filially pious child will conclude that he should not conceal the crime. But can that decision be made without recourse to standards of rationality that transcend the practice? This is the crux of the debate between Habermas and Gadamer. Habermas argues that there are trans-cultural standards, while Gadamer appears to rejects such standards.

Habermas contrasts critical-theoretical reflection with Gadamer's position. For Habermas, tradition can be overcome through critical reflective thinking. In other words, although the conventional value system might constitute the horizon of value system of each individual in a particular culture, as exemplified by the example of filial piety in the Confucian East Asian case, the critical assessment of such could ultimately reveal the fundamentally conflictual structure of society. Against the appropriation of merely conventional value, the task is to reveal hidden pre-understandings, that is, forces that condition us without our knowledge. Filial piety might have served as a value system-prejudice or tradition in Gadamer's terminology-in Confucian East Asian culture; nonetheless, it has very significant implications for the autonomy of each individual. As aforementioned in this paper, 
filial piety is an implicit rejection of the reciprocal and free relationship between parents and their children, and is thus incompatible with freedom and equality.

The fundamental value of filial piety is inseparable from Confucian East Asian culture. Critical thinking aims to reveal the conflictual structure of historicity. This recognition subsequently opens up a path leading towards something which can be cautiously referred to as critical interpretation. When we become aware of power relations in all interpretive situations, critique allows a multiplicity of conflicting perspectives or interpretations to be acknowledged. Critique, in this sense, takes place as a force which fundamentally liberates the conflict of interpretations, taking as its guide the maxim that no one's voice should be silenced. Critical reflection can make explicit the implicit presuppositions of, for example, particular interpretative situations (as shown in the concept of filial piety in Confucian East Asian culture) even if it is not possible to make explicit all pre-understandings.

Certainly Gadamer's insistence on tradition has been criticized from the "left" as "conservative" (Bernstein 295; Wolin 44). In particular, these critics attack the notion of a tradition for not allowing any scope for the critique of ideology residing within tradition (Eagleton 72; Caputo 112; Habermas, Logic of Social Science 168). John Caputo claims that Gadamer is critically concerned with looking backward, involved with how truth gets passed down and never places such truth in questionthat is, "the deep unity of tradition is always safe" (111). Likewise, Terry Eagleton maintains that Gadamer's notion of tradition implies "a grossly complacent theory of history, which is not a place of struggle, but almost "a club of the like-minded" (72).

Every society has its own conventional values and norms, and filial piety is regarded as one of the most influential characteristics of Confucian ethics. The practice of filial piety has acquired its normative power as a result of two thousand years of cultural development, underpinned by both practice and ideology. Gadamer argues that it is impossible for those brought up in such a tradition to transcend it, because human beings are finite and historical. If we follow Gadamer's standpoint, then there is no standpoint outside Confucian culture that could ultimately allow members of that culture to reject filial piety. This does not mean that criticism is not possible, but rather that there is no ultimate grounding or justification. However, for Habermas, the ethical practice in a particular tradition and cultural context can and should be modified through critical reflection. A critical undertaking can never be completed; it creates an object, which must in its turn be criticized. Critique must be constantly started again, precisely because the dimension of conflict giving the critique the space to operate affects also the critical undertaking itself. In this context, Gadamer's position is merely the appropriation of the norms and conventions of the status quo. Thus, Habermas tries to solve the problems 
surrounding tradition and authority from an ethical and normative standpoint, which allows for a judgment of right or wrong.

The primary focus of this paper has been the explication of the HabermasGadamer debate against the background of East Asian culture, specifically the practice of filial piety. Although this paper is not merely focusing on the concept of filial piety itself, the practice nevertheless powerfully illustrates the difference between Habermas and Gadamer. Without criteria for assessing normative rules, any kind of power relationship, however oppressive, can be subsumed under "filial piety." As has been maintained throughout the paper, the concept of filial piety presupposes the authoritarian inequality between parents and children, or to be more precise, between a father and his children. In this sense, the unequal authoritarian relationship between parents and children in Confucian East Asian culture can be judged as not merely unjust in an intuitive sense, but also irrational and unfair. Habermas and Gadamer might agree that there is nothing wrong with the reciprocal relationship between parents and children if it is connected to the emotional bond between them. However, there is a clear disparity between Habermas and Gadamer with regard to how they might interpret and possibly justify filial piety. The traditional idea of filial piety in Confucian East Asian culture has reinforced the absolute authority of the parents over the children. In other words, having respect for the parents is the expected behavior of children because it is one of the most important obligatory values in Confucian East Asian culture. The children's attitude toward their parents is the primary value in evaluating whether the children are filial or unfilial. Thus, disobedience to one's parents is considered unfilial behavior in Confucian East Asian culture. It means that children have to obey their parents without question. 


\section{Glossary of Chinese Characters and Books}

Analects (論語)

Chün-tzu (true gentleman, 君子)

Dao (Way, 道)

$L i$ (propriety, 禮)

Ren (humanity, 仁)

Sangkang (Three Bonds, 三綱)

Shi (scholars, interior officers, 士)

Three Bonds (三綱)

Xiao (filial piety, 孝)

XiaoJing (The Classic of Filial Piety, 孝經)

Zhong (loyalty, 忠) 


\section{Notes}

1. This article is based on an excerpt of author's unpublished doctoral thesis, and a rewritten and restructured version of it. Kim, Donghyun. Reason, Tradition, and Authority: A Comparative Study of Habermas and Gadamer. (Unpublished Doctoral Dissertation). University of Glasgow, United Kingdom. 2011.

2. I use Chinese characters which correspond to English in order to minimize the confusion of the original meaning of the Chinese characters.

3. The philosophical debate between Habermas and Gadamer is of importance in view of the concepts of tradition, authority, and reason. Habermas primarily pinpoints Gadamer's espousal of tradition as an irrational and unconditional entity by emphasizing the role of the critical reflection of reason ("A Review of Gadamer's Truth and Method" 335-363). In his reply to Habermas' criticism, Gadamer defends the role of tradition in his philosophical hermeneutics as "interpretative" logos that can be understood as both language and reason carrying out its critical strength ("Rhetoric, Hermeneutics, and the Critique of Ideology" 274-292). However, the commitment of interpretative design in Gadamer's appropriation of tradition can be interpreted as merely a conservative impression. The debate between the two mainly lies in the acceptance of uncritical tradition and the recognition of ideology critique provided by Gadamer and Habermas, respectively. The extensive commentaries and more detailed descriptions regarding the debate between Gadamer and Habermas can be found in Alan How's book The Habermas-Gadamer Debate and the Nature of the Social: Back to Bedrock. Averbury, 1995.

4. In the first chapter of The Classic of Filial Piety, Confucius argues that "filial piety is the root of all virtue" (XiaoJing, 1) and "All virtue means the five virtuous principles, the constituents of humanity (ren, 仁): benevolence, righteousness, propriety, knowledge, and fidelity." See XiaoJing, http://www.chinapage.com/ confucius/xiaojing-be.html. Accessed on 17 June 2017.

5. The name of the author of The Classic of Filial Piety is unknown. It is attributed to a conversation between Confucius (孔子) and one of his disciples named Zeng $\mathrm{Zi}$ (曾子).

6. This idea is first seen in the Hanfeitzu, in the section on "Zhongxiao" ("Loyalty and Filial Piety").

7. Ng also argues that there are affinities between Gadamer and Confucius. He asserts that Gadamer's philosophy "is seemingly consonant with the Confucian conception of knowledge-the veneration of tradition and the ascription of authority to the classical; the ontological sense of continuity and mutuality with history and culture; the resistance to the atomistic objectification of nature; the immersion of the self in the world through moral self-cultivation as fiduciary commitment; and the sober acceptance of the integrity of language as the embodiment of reality" ("Chinese Philosophy" 377).

Kritika Kultura 33/34 (2019/2020): 60-064

(c) Ateneo de Manila University

<http://journals.ateneo.edu/ojs/kk/> 
8. Gadamer's philosophical hermeneutics is concerned with the ontological interpretation of human life by understanding and recognizing that there are overpowering and uncontrollable forces which are set against a subjective historical nature. From this angle, one which has generated much controversy among his critics, the use of his term "philosophical hermeneutics" ultimately rests upon temporal completion in relation to the "historically effected consciousness." For Gadamer, the mode of human understanding is fundamentally conditioned by the "historically effected consciousness" because human beings are never free from historical conditions.

9. Confucius claimed that there was an indivisible connection between tradition and the Way (Dao, 道); people should follow the Way as they follow tradition. Gadamer's acknowledgement of tradition and the practice of the Way in Confucian philosophy serve as the foundation for those who seek understanding and knowledge. In the Confucian understanding of tradition, it is in this sense that man can be said to make the Way great. The Way (Dao, 道) may be seen as the actualization of the moral virtues of the true gentleman (Chün-tzu, 君子). Confucius describes the role of the true gentleman in Analects 1.2: "A superior man is devoted to the cultivation of fundamentals; when they are firmly established, the Dao will grow" (Lau, Analects 1.2). 


\section{Works Cited}

Bellah, Robert. Tokugawa Religion. The Free Press, 1957.

Bernstein, Richard J. "From Hermeneutics to Praxis." Hermeneutics and Praxis, edited by Robert Hollinger, Notre Dame UP, 1985, pp. 272-298.

Caputo, John. Radical Hermeneutics. Indiana UP, 1987.

Chai, Ch'u, and Winberg Chai. The Humanist Way in Ancient China. Bantam, 1965.

Chan, Alan. "Confucian Ethics and the Critique of Ideology." Asian Philosophy, vol. 10, no. 3, 2000, pp. 245-261.

--. "Philosophical Hermeneutics and the Analects: The Paradigm of 'Tradition." Philosophy East and West, vol. 34, no. 4, 1984, pp. 421-436.

Cheng, Zhongying. "On Confucian Filial Piety and Its Modernization: Duties, Rights, and Moral Conduct." Chinese Studies in Philosophy, vol. 2o, no. 2, 1988, pp. 48-88.

Chow, Kai-wing, Tze-ki Hon, Hung-yok Ip, and Don C. Price, editors. Beyond the May Fourth Paradigm: In Search of Chinese Modernity. Stanford UP, 1960.

Eagleton, Terry. Literary Theory: An Introduction. U of Minnesota P, 1983.

Fan, Ruiping. "Which Care? Whose Responsibility? And Why Family? A Confucian Account of Long-Term Care for the Elderly." Journal of Medicine E Philosophy, vol. 32, no. 5, 2007, pp. 495-517.

Finlayson, Gordon. Habermas: A Very Short Introduction. Oxford UP, 2005.

Gadamer, Hans-Georg. "The Hermeneutics of Suspicion." Hermeneutics: Questions and Prospects, edited by Gary Shapiro and Alan Sica, U of Massachusetts P, 1984, pp. 54-65.

-.. "Reply to My Critics." The Hermeneutic Tradition, edited by Gayle L. Ormiston and Alan D. Schrift, State U of New York P, 199o, pp. 273-297.

--. "Rhetoric, Hermeneutics, and the Critique of Ideology." The Hermeneutics Reader, edited by Kurt Muller-Vollmer, Continuum, 1986, pp. 274-292.

-.. Truth and Method. Translated by W. G. Doepel, Sheed and Ward, 1975.

-.. Truth and Method. Translated by J. Weinsheimer and D. G. Marshall, Continuum, 1989.

Habermas, Jürgen. "On Hermeneutics' Claim to Universality." The Hermeneutics Reader, edited by K. Muller-Vollmer, Continuum, 1986, pp. 294-319

--. On the Logic of the Social Sciences. Translated by Shierry W. Nicholson and Jerry A. Stark, Polity, 1988.

--. "A Review of Gadamer's Truth and Method." The Hermeneutical Tradition: From Ast to Ricoeur, edited by Gayle L. Ormiston and Alan Schrift, State U of New York P, 199o, pp. 213-244.

--. "A Review of Gadamer's Truth and Method." Understanding and Social Inquiry, edited by Fred R. Dallmayr and Thomas McCarthy, U of Notre Dame P, 1977, pp. 335-363.

--. The Theory of Communicative Action, Vol. 1: Reason and the Rationalization of Society. Translated by T. McCarthy, Beacon Press, 1984. 
Hamilton, Gary G. "Patriarchy, Patrimonialism, and Filial Piety: A Comparison of China and Western Europe." The British Journal of Sociology, vol. 41, no. 1, 199o, pp. 77-104.

Hashimoto, Akiko. "Culture, Power, and the Discourse of Filial Piety in Japan: The Disempowerment of Youth and Its Social Consequences." Filial Piety: Practice and Discourse in Contemporary East Asia, edited by Charlotte Ikels, Stanford UP, 2004, pp. $182-197$.

Held, David. Introduction to Critical Theory: Horkheimer to Habermas. Hutchinson, 1980.

How, Alan. The Habermas-Gadamer Debate and the Nature of the Social: Back to Bedrock. Avebury, 1995.

Hoy, David, and Thomas McCarthy. Critical Theory. Blackwell, 1994.

Huang, Yong. Introduction. Confucian Filial Piety: Root of Morality or Source of Corruption, special issue of Contemporary Chinese Thought, vol. 39, no. 1, 2008, pp. 3-14.

Huang, Yusheng. "The Starting Point of Universal Ethics: Free Individual or Relational Character." Contemporary Chinese Thought, vol. 39, no. 1, 2007, pp. 35-45.

Hwang, Kwang-Kuo. "Filial Piety and Loyalty: Two Types of Social Identification in Confucianism." Asian Journal of Social Psychology, vol. 2, 1999, pp. 163-183.

Ivanhoe, Philip J. "Filial Piety as a Virtue." Filial Piety in Chinese Thought and History, edited by Alan Kam-leung Chan and Sor-hoon Tan, RoutledgeCurzon, 2004, pp. 189-202.

Jordan, David K. "Filial Piety in Taiwanese Popular Thought." Confucianism and the Family, edited by Walter H. Slote and George. A. de Vos, State U of New York P, 1988, pp. 267-284.

Jung, Hwa Yol. "A Metacommentary on the Current Debate on the Problematique of Filial Piety." Dao, vol. 7, 2008, pp. 131-134.

Kunio, Mugitani. "Filial Piety and 'Authentic Parents' in Religious Daoism." Filial Piety in Chinese Thought and History, edited by Alan Kam-leung Chan and Sor-hoon Tan, RoutledgeCurzon, 2004, pp. 110-121.

Lau, D. C. Confucius: The Analects. Penguin Books, 1979.

Liem, L. C. "On the Fringe of the Problem of Aged People." Vietnamese Studies, vol. 34, 1998, pp. 73-77.

Liu, Junping. "Rethinking Justice: Toward an East-West Approach in Understanding Filial Piety." Contemporary Chinese Thought, vol. 39, no. 1, 2007, pp. 75-86.

Liu, Qingping. "Filiality versus Sociality and Individuality: On Confucianism as 'Consanguinitism.'” Philosophy East and West, vol. 53, no. 2, 2003, pp. 234-250.

Lee, Hiwan. "Strategies for Improvement of Filial Behavior Encouragement and Support Policy in South Korea." Korean Policy Sciences Review, vol. 20, no. 3, 2016, pp. 171-188.

Mendelson, Jack. "The Habermas-Gadamer Debate." New German Critique, vol. 18, 1979, pp. 44-73.

Ng, On-cho. "Chinese Philosophy, Hermeneutics, and Onto-Hermeneutics." Journal of Chinese Philosophy, vol. 30, no. 3, 2003, pp. 373-385. 
--. "Toward a Hermeneutic Turn in Chinese Philosophy: Western Theory Confucian Tradition, and CHENG Chung-ying"s Onto-hermeneutics." Dao, vol. 6, 2007, pp. 383-395.

Palmer, Richard E. "Gadamer and Confucius: Some Possible Affinities." Journal of Chinese Philosophy, vol. 33, no. 1, 2006, pp. 81-93.

Roetz, Heiner. "Confucianism and Familism: A Comment on the Debate between Liu and Guo." Dao, vol. 7, 2008, pp. 41-44.

--. "Confucianism between Tradition and Modernity, Religion, and Secularization: Questions to Tu Weiming." Dao, vol. 7, 2008, pp. 367-380.

Ronald, Richard. "Home Ownership, Ideology and Diversity: Re-evaluating Concepts of Housing Ideology in the Case of Japan." Housing, Theory and Society, vol. 21, no. 2, 2004, pp. 49-64.

Rosemont, Henry, and Roger T. Ames. "Family Reverence (xiao 孝) as the Source of Consummatory Conduct (ren 仁).” Dao, vol. 7, 2008, pp. 9-19.

Slote, Walter H. "Psychocultural Dynamics within the Confucian Family." Confucianism and the Family, edited by Walter H. Slote and George A. De Vos, State U of New York P, 1998, pp. 37- 52.

Sung, Kyu-Taik, and Bok Song. "A New Look at Ideals and Practices of Filial Piety: The Case of Exemplary Filial Persons." Global Economic Review, vol. 30, no. 3, 2001, pp. 35-49.

Tan, Sor-hoon, and Alan Chan. Introduction. Filial Piety in Chinese Thought and History, edited by Sor-hoon Tan and Alan Chan, RoutledgeCurzon, 2004, pp. 1-11.

Tu, Weiming. Confucian Thought: Selfhood as Creative Transformation. State U of New York P, 1985.

-.. "Confucius and Confucianism." Confucianism and the Family, edited by Walter H. Slote and George A. de Vos, State U of New York P, 1998, pp. 3-36.

Tzu, Han F. Han Fei Tzu: Basic Writings. Translated by Burton Watson, Columbia UP, 1963. Warnke, Georgia. Gadamer: Hermeneutics, Tradition, and Reason. Stanford UP, 1987.

Wellmer, Albrecht. "Practical Philosophy and the Theory of Society: On the Problem of the Normative Foundations of a Critical Social Science." The Communicative Ethics Controversy, edited by Fred Dallmayr, MIT Press, 1990, pp. 293-329.

Wolin, Richard. "Nazism and the Complicities of Hans-Georg Gadamer: Untruth and Method." The New Republic, vol. 4, 200o, pp. 36-45.

XiaoJing, http://www.chinapage.com/confucius/xiaojing-be.html, Accessed 17 June 2017.

Xunzi, Xunzi: A Translation and Study of the Complete Works. Translated by John Knoblock, Stanford UP, 1994.

Yim, Dawnhee. "Psychocultural Features of Ancestor Worship in Modern Korean Society." Confucianism and the Family, edited by Walter. H. Slote and George A. de Vos, State U of New York P, 1998, pp. 163-186. 